\title{
Stem cells perspective in cure and management of diabetic retinopathy
}

\author{
Laiba Batool ${ }^{1}$, Amina Arif ${ }^{1 *}$, Rafique Ahmed ${ }^{2}$, Kashif Raza Khan ${ }^{2}$ and \\ Muhammad Saqib Shahzad ${ }^{1}$ \\ 1. University of Central Punjab, Lahore, Pakistan \\ 2. Govt Kot Khawaja Saeed Teaching Hospital, Lahore, Pakistan \\ *Corresponding author's email: draminaarif@ gmail.com \\ Citation \\ Laiba Batool, Amina Arif, Rafique Ahmed, Kashif Raza Khan and Muhammad Saqib Shahzad. Stem cells perspective \\ in cure and management of diabetic retinopathy. Pure and Applied Biology. Vol. 10, Issue 4, pp1411-1426. \\ http://dx.doi.org/10.19045/bspab.2021.100147
}

Received: 03/12/2020 Revised: 19/02/2021

Accepted: 18/03/2021

Online First: 22/04/2021

\section{Abstract}

Diabetic retinopathy is the trending issue of the vision loss worldwide that occurs due to mismanagement of glycemic level of the diabetic patients. In diabetic retinopathy neurons and capillaries, which are associated with retina, start to damage that result in alteration in the vision function of retina. Long term effective strategy for diabetic retinopathy has not been proposed yet but the stem cells can make it possible to prevent or cure diabetic retinopathy. Stem cells have the potential of repairing and replacement of damaged or defected retinal cells. Different types of stem cells like induced pluripotent stem cells, mesenchymal stem cells, some other factors like CD34+ cells, HLA factors etc have a significant role in the treatment of diabetic retinopathy. In this review, other than the role of stem cells, we have discussed the management and screening of diabetic retinopathy. Management and screening, are the parts of the strategy to reduce the risk of diabetic retinopathy that act like the tools to treat diabetic retinopathy. As stem cells are the most feasible source of treatment of diabetic retinopathy. Management and screening of diabetic retinopathy at early stage could be helpful in treatment even when the patient doesn't show symptoms. The stem cell therapy in diabetic retinopathy offers a long lasting treatment option.

Keywords: CD34+ cells; Diabetic retinopathy; HLA factors; Induced pluripotent stem cells; Mesenchymal stem cells

\section{Introduction}

Stem cells are the non-differentiated cells that have the potential to divide and give birth to a number of new stem cells. These cells might be of same type or different from each other and they are categorized according to their functions. Stem cells can be obtained from different sources, in a human body there are main sources to obtain stem cells; bone marrow, adipose tissues and blood [1]. Stem cells are used in bone marrow transplantation if there is need to avoid the risk of rejection of cells then the stem cells can also be obtained from umbilical cord blood. Many medical issues like osteoarthritis, blood cell formation, blindness and vision impairment, wound healing, infertility, HIV/AIDS, cartilage repair, nervous system repair, development of pancreatic beta cells and regrowth of teeth are being treated with the help of stem cells [2]. Diabetic retinopathy (DR) is a common cause of blindness all over the world. Bone marrow 
mesenchymal stem cells (BMSCs) have been considered as a promising strategy for retinal regeneration in the treatment of DR [3].

Stem cells have been confirmed to be involved in the occurrence and development of diabetic retinopathy. Globally, the current authoritative studies have focused on basic research towards the stem cell treatment of diabetic retinopathy [4].

One of the trending issues which are being treated with the help of stem cells is diabetic retinopathy. Diabetic retinopathy is an eye disease in which the retina gets affected due to diabetes. The end result of this disease is blindness. Arteries and neurons linked with retina get affected badly. But the narrowing of retinal arteries and damage of neurons are the initial changes. Later on outer retina starts to get damaged which also disturbs the visual functioning and dysfunctioning of blood retinal barrier. This blood retinal barrier protects the retina from any toxic element to get in contact with it.

The mammalian retina displays incomplete intrinsic regenerative capacities; therefore, retina degeneration is a major cause of irreversible blindness such as glaucoma, agerelated macular degeneration and diabetic retinopathy. These diseases lead to the loss of retinal cells and serious vision loss in the late stage. Stem cell transplantation is a great promising novel treatment for these incurable retinal degenerative diseases and represents an exciting area of regenerative neurotherapy [5].

There are different stages of disease; nonproliferative diabetic retinopathy and proliferative diabetic retinopathy (Fig. 1).

Non-proliferative diabetic retinopathy

It is the early stage of diabetic retinopathy. At this stage vessel swell due to leakage of a fluid. This fluid causes swelling in surrounding tissues although the said fluid clears up on its own but sometimes it remains as such and disturbs the vision that also leads towards bleeding in retina.

\section{Proliferative diabetic retinopathy}

With the progress of disease nonproliferative retinopathy turns into a proliferative stage. Vasodilation of new vessels takes place and the vessels lack oxygen. These new vessels arise along with the retina and without any proper treatment these vessels start to bleed. Fill-up of a gelatinous material called vitreous humor takes place which makes the vision cloudy. Sometimes the severe end results may be retinal detachment.

With the passage of time lower membrane of retina thickens that results the degeneration of capillaries. At this stage capillary lose their cells called pericytes and vascular smooth muscles. This all result in loss of blood flow [6]. Macular edema develops in a number of patients. In this condition a fluid leaks from the damage cells onto the macula. It is the part of the retina that helps us to see the details. Macular edema is an important disclosure of diabetic retinopathy and also a most common cause of modest loss of vision [7]. Many patients with type 1 diabetes loss their vision. The range of this vision loss is up to $3.5 \%$ [8]. Diabetic retinopathy is one of the leading cause of blindness in diabetic patients. But to get rid of this situation no particular treatment has been discovered yet for long term beneficial results. For treatment of diabetic retinopathy bone marrow derived stem cells are the most possible prospects [9]. Diabetic retinopathy degenerates the retina and the mesenchymal stem cells (MSCs) that have the ability to restore and to delay the degenerative process in retinopathy [10]. In addition, MSCs have the potential to treat diabetes although the after effects of these cells are still controversial. The treatment of diabetes through MSCs might be very helpful to delay the effect of diabetic retinopathy. During early diabetes loss of pericytes and neuroretinal damage takes place due to the oxidative stress on retina [11]. MSCs have the ability to treat with the species that cause 
the oxidative stress. MSCs sought out this stress through the expression of sulfoxide reductase A. MSCs can protect from degenerative process of neuroretina and prevents apoptosis. MSCs also promotes the regeneration of neuroretinal tissues [12]. The mechanism of working of ESCs in terms to treat diabetic retinopathy is not clear yet.

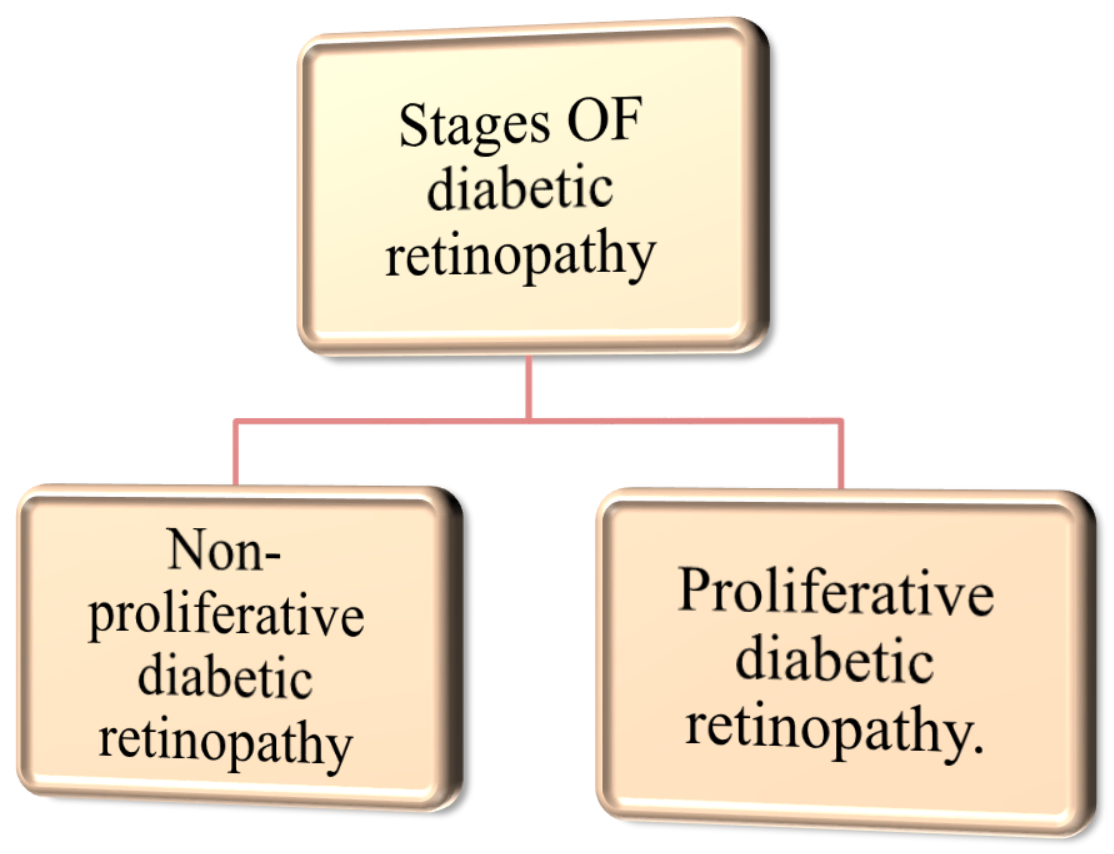

Figure 1. Stages of diabetic retinopathy

Non-proliferative diabetic retinopathy and proliferative diabetic retinopathy

\section{Pluripotent stem cells (PSCs)}

According to the recent developments pluripotent stem cells PSC (PSC) are used to resolve diabetic retinopathy issues. These cells are derived from CD34+ cord blood cells [13]. When we are concerned with the treatment of retinal capillaries PSCs are helpful to develop a feasible strategy. The cells which are derived from CD34+ cord blood cells give convenient strategy for the regeneration of cellular capillaries.

Along with the help of stem cells many other developments are emerging to overcome this common issue of diabetic retinopathy. As the diabetic retinopathy is now a day's most common reason of vision loss in many people around the world. This issue needs to be managed properly. Most of the recent developments are focusing on the management of diabetic retinopathy.
Including early diagnosis and immediate treatment. Quick treatment at initial stage can reduce the chances of macular edema and vision loss. According to the recent managements diabetic patients need a proper checkup according to the type of the diabetes. The patients with type 1 diabetes patients need a checkup after 3-5 years. Patients with type 2 diabetes need a treatment immediately from the diagnosis of type 2 diabetes. Mostly patients are unaware about the risk factors of the diabetes like diabetic retinopathy/vision loss. Education must be given to patients and doctors about the risk factors. But this education needs to be concise in perspective to give awareness about the results. After many researches it has been revealed that genetic factors are also responsible for the severity of diabetic retinopathy. Some histocompatibility antigens are responsible 
for the effects of DR. HLA-DR4 are that HLA factor. Patients that have high level of HLA-DR4 have more severe diabetic retinopathy than the other patients. Another factor which is responsible for seriousness of diabetic retinopathy is glycemic control. Better glycemic control can manage the severe results of diabetic retinopathy. Bad glycemic control can lead to many problems [14]. Severity of diabetic retinopathy can be changed during pregnancies. Association of high level of fasting blood glucose level and a higher level of serum progesterone concentration in body are responsible in progression of diabetic retinopathy. Non proliferative diabetic retinopathy can turns into proliferative diabetic retinopathy. There is no written data about this factor. That's why this is still a controversial that either pregnancy is an important risk factor or not. Blood pressure is also a factor of concern in association with diabetic retinopathy. The fluctuated level of blood pressure being noticed with PDR [15]. High blood pressure itself is a risk factor. Proliferative retinopathy and high blood pressure occurs simultaneously.

Above given factors are of concern in perspective of seriousness of diabetic retinopathy. These factors need to be addressed if DR is concerned to be managed. Stem cells have the ability to renew the damaged cells. Stem cells are used to replace photoreceptors to overcome the risk of vision loss through retinal diseases. Stem cells are easy to phase out the damage beneath the retina. Stem cells repair the capillaries and neurons associated with retina [16]. To facilitate the human therapies, the concentration has moved towards the cells transplantation through stem cells. Stem cells are also used for the induction of photoreceptors [17]. Now days the focus of the recent work is the generation of photoreceptors from the induced pluripotent stem cells [18]. For the sake of repair of neurons of retina, it may be more convenient to use adult stem cells which are already segregated into neurons. It is impossible yet to propose any long term prevention but the stem cells are the source to overcome the dangerous risks. Adult stem cells propose a way to repair the damaged neurons. The neurons network which is not yet damage could be replaced with the normal cells [19]. Bone marrow derived stem cells are also used for diabetic retinopathy. CD34+ cells are supposed to be more rapid in action for regeneration of cells [20]. According to recent researches another type of bone marrow derived cells has been explored. This type is CD14+ cells. These cells unlike the CD34+ cells are more efficient especially in perspective of diabetic retinopathy [21].

Many techniques have been explored but diabetic retinopathy is still the issue to focus on. This is the trending cause of vision loss. In the sense of future prospect many factors along with stem cells need to be considered for long term results or preventions. According to the American diabetes association the factor of elevated blood pressure level need to be notice because fluctuation in blood pressure level affects the blood barrier associated with retina [22]. Currently long term effective treatments are not available for diabetic retinopathy but the aid of stem cells could be good source to overcome this problem.

\section{Materials and Methods}

Diabetic retinopathy is treated through mesenchymal stem cells and endothelial progenitor cells (Fig. 2).

\section{Mesenchymal stem cells Modulation of ROS production through mesenchymal stem cells}

Reactive oxygen species are the oxygen derived molecules. These molecules react with a number of molecules such as proteins, lipids and nucleic acid. Increased number of reactive oxygen species inhibits the mesenchymal stem cells proliferation. High 
RPS level cause cellular damage and also dysfunctioning. Whereas mesenchymal stem cells have a low level of ROS and a high level of an antioxidant called glutathione [23]. Oxidative stress induces by ROS introduces many changes. These changes include; decrease in proliferation, decrease in certain surface antigens for example, CD13, CD29 and CD44. This stress also diminishes the ability of suppressing T cells [24].

Mesenchymal stem cells to target swelling

Low grade chronic swelling appears as a result of pathogenesis of diabetic retinopathy [25]. Umbilical cord mesenchymal stem cells UC-MSCs suppressed inflammation [26]. Hypertension and hyperglycemia induces apoptosis and oxidative stress. This results the increase in pro-inflammatory intercessors such as IL1 $\alpha$, IL1 $\beta$, IL6, IL8, MCP-1, TNF $\alpha$, and IL18 and some chemokines such as CCL2, CCL5, CXCL8, CXCL10, and CXCL1. These factors have been observed in patients with advanced DR and proliferative DR [27]. Although T-helper cells do not found as infiltrates but plays minor role in local activities. There are some different indications in different stages of advanced DR. There is difference in balance in $\mathrm{T}$ helper cells and cytokine in serum and vitreous [28].

Mesenchymal stem cells and T-cells: According to many reports in diabetic patients MSCs exert anti-diabetic affects by affecting the T-cells [29]. When T-cells are triggered by different mitogenic stimuli such as PHA or anti-CD3/anti-CD28 monoclonal antibodies then the MSCs exert a strong suppressive effect on T-cells proliferation [30]. The mechanism of action of T-cells is still a controversy. But many studies revealed the cell-cell interaction and MSC immunomodulation. There are some of the indications about the action of T-cells in DR. There is not any $\mathrm{T}$-cell in the retina thus the effect on T-cells may be autoimmune than local responses [31].

Helper $\mathrm{T}$ cells are the part of adaptive immune system and are responsible for all the adaptive immune responses. Helper $\mathrm{T}$ cells activate the cytotoxic $\mathrm{T}$ cells to kill the targeted infected cell. $\mathrm{T}$ helper cells are derived from local inflammation, acts as a conductor in chronic and acute responses. CD4+ and CD8+ T cells infiltrate the vitreous of proliferative diabetic retinopathy. Helper $\mathrm{T}$ cells are responsible for the determination of the cytokinine; that what cytokinine will allow the immune system to be more beneficial for the host. Different helper $\mathrm{T}$ cells acts against different attack of different organism. For example, Th1 cells give a cell mediated response. The response is against intracellular bacteria and protozoa. Th2 cells give a humoral immune response and the response is against extracellular parasites. Another type is Th17 helper T cells. These cells are the subset of helper $\mathrm{T}$ cells. These cells are different from Th1 and Th2 cells. Th17 helper $\mathrm{T}$ cells give response against extracellular pathogen and fungi.

\section{CD34+ cells and endothelial progenitor cells}

CD34+ cells circulate as endothelial progenitor cells. This circulation has great importance in regeneration and angiogenesis. CD 34 is a transmembrane cell surface protein. These cells are in higher concentration in bone marrow but according to a few studies CD34 cells can also be obtained from umbilical cord blood, fetal liver and adipose tissues. CD34 cells which are derived from bone marrow are considered to be more effective because adult CD34 cells can differentiate in retinal cells [32]. Patients with proliferative diabetic retinopathy PDR have a higher level of circulation of CD34+. High level of glucose in diabetic patients is the main cause of vision loss through diabetic retinopathy. In Proliferative diabetic retinopathy ischemia is caused due to the 
vascular damage of retina. EPCs have the ability of repair at the sites of ischemia [33]. The level of circulation of EPCs in both the patients with type 1 and type 2 diabetes is different [34]. Poor glycemic control is responsible for the variation in the numbers of circulating EPCs. Poor control of glucose decreases the numbers of circulating EPCs whereas normal control of glucose level increases the number of EPCs. EPCs are the potential biomarkers in diabetic retinopathy [35]. As the result of diabetic retinopathy both the endothelial cells and pericytes are affected. EPCs are used for the treatment of DR. First of all, in the treatment of DR through EPCs determination of cell type to be used and cell number should be done. If a cell is single, then endothelial colony forming cells ECFCs need to be considered to use. Second is the estimation of the number of cells to be used. If the cells going to be introduced through injections, then the route of action must be chosen along with the estimation of number of cells [36]. Thirdly that population should be used that are more likely to benefit from treatment with EPCs. Fourthly, the most appropriate outcome measures that would allow the arrangements for proper treatment. At last the compilations of data from the clinical trials of action of EPCs in diabetic retinopathy.

\section{HLA factors in diabetic retinopathy}

Human leukocytes antigen system HLA factors plays important role in immune responses In DR. Studies have shown the relationship between HLA factors and destruction of pancreatic islets in the patients who are insulin dependent [37]. The presence of HLA factor determines the severity of diabetic retinopathy. The patients with negative HLA factors have less severity of DR either they are insulin dependent. HLAA24 is the most considerable factor. HLA factors sometimes considered as the markers to examine the severity of DR [38]. HLA factors consideration is the strongest factor in development of proliferative diabetic retinopathy. According to many findings HLA-A24 has an indirect association with the development of diabetic retinopathy. This association was conciliated by the long term glycemic control and function of residual B function; another indirect association has been reported [39].

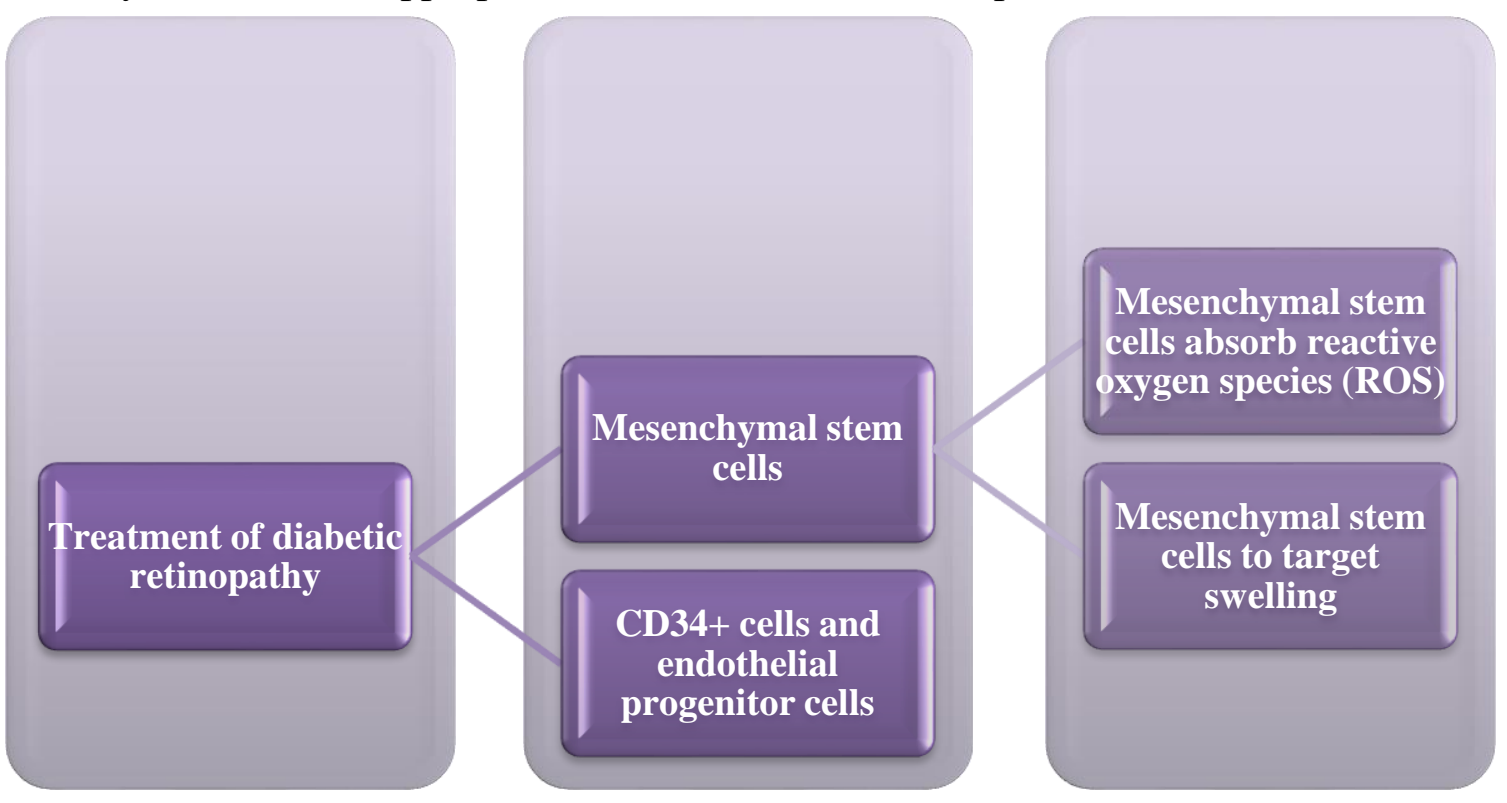

Figure 2. Treatment options of diabetic retinopathy

Diabetic retinopathy is treated through mesenchymal stem cells and endothelial progenitor cells 


\section{Current prospect}

As the diabetic retinopathy is the severe disease and do not have any long term prevention technique yet but the stem cells have the potential to give a long term relaxation from risk of diabetic retinopathy. Retina is an easy to access tissue in the body, stem cells can be injected at the defected areas [40]. Stem cell therapies are the most feasible way to protect against diabetic retinopathy. These stem cell therapies are based on two different theories such as, neuroprotective effects and cell replacement. Cell replacement therapy for diabetic retinopathy something different from the other therapies for other retinal diseases [41]. Stem cell therapy for diabetic retinopathy is different because of dysfunctioning and death of pericytes, vascular smooth muscles and endothelial cells which are linked with retina [42]. Therefore, the therapies for DR are concerned to repair the retinal vascular system instead to replace the vascular system. Endothelial progenitor cells are considered to be the sufficient participants of stem cell therapy in DR [43]. Along with the selection of stem cells the introduction of stem cells in defected retinal areas is also a point to be noticed. The introduction of stem cells in defected area could be done by subretinal, intravitreal and intravenous injections [44]. Different types of stem cells are used to treat DR. Adipose modified stem cells (ADMSC), induced pluripotent stem cells and mesenchymal stem cells. (Fig. 3).

\section{Adipose mesenchymal stromal cells}

ADMSCs could be an effective source to treat DR that are introduced intravenously in the retina. ADMSCs are able to reduce blood glucose level and also to repair the blood retina breakdown which is the result of DR [45]. These stem cells have advantage to use because they are less complex but a risk level also exits. During the transplantation studies of stem cells in rat these cells introduced in the retina. These cells were found to exit in the targeted organs when these cells used to cross the retinal blood barrier [46].

\section{Induced Pluripotent Stem Cells}

Use of iPSCs of swine for retinal treatment has been achieved. Retinal cells of pigs are used because the human eye and a pig eye have many similarities in terms of anatomy and histological structure [47].

Retinal pigment epithelium RPEs plays an important role in the vision function of retina. The iPSC derived RPEs found very feasible in visual cycles in human eye. During the experimental studies these RPEs were found very effective to treat the degenerated issues in DR [48]. Although diabetic retinopathy is still do not have any long term treatment strategy but iPSCs are the most important source for the repair of damage cells in DR. Along with the challenges that remain at their place in the future, these iPSCs considered to be the feasible strategy for the treatment of diabetic retinopathy [49]. Human induced pluripotent stem cell-derived MGCs (hiMGCs) could be an alternative to primary human Muller glial cells (pMGCs) and an extremely valuable tool to help to understand and model glial cell involvement in retinal disorders, including DR [50].

\section{Embryonic stem cells}

These cells have the potential to differentiate in different types of cells. These cells are also recommendable for the replacement of retinal cells in DR. The use of these cells could be the best strategy. ESCs are being in use to obtain progenitor cells which further differentiate into retinal cells such as photoreceptors. According to recent studies ESCs are also applicable to develop RPEs [51]. If we need to avoid the host rejection issue than these cells are very favorable. Stem cells are being in use for different strategies. For example, replacement and repair of damaged cells. Stem cells replace the photoreceptors. The replacement of photoreceptors through stem cells could be very helpful to restore the vision loss in DR. 
Stem cells seems more convenient than any other strategy to treat DR. SC are more feasible to migrate and integrate at the damaged area of retina [52]. The development of photoreceptors from induced pluripotent stem cells is the work of focus in recent studies [53]. Retinal pigment epithelium plays important role in many of the metabolic functions of retina. Due to DR the dysfunction of RPEs takes place. This leads to the vision problems in diabetic patients. Stem cells are very feasible to replace these damaged cells to restore the vision functions of retina [54]. For the development of cells both in in-vitro and invivo conditions iPSCs are the most favorable cells [55].

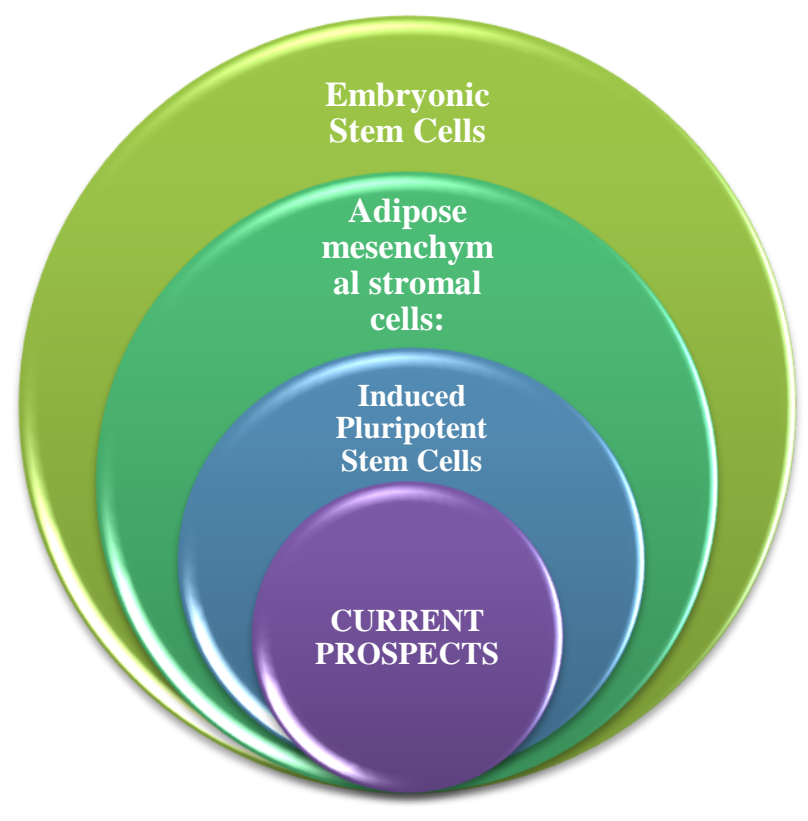

Figure 3. Different types of stem cells are used to treat DR.

Adipose modified stem cells (ADMSC), induced pluripotent stem cells and mesenchymal stem cells

\section{Some future prospects}

In current status and future there is a lot of work to resolve the hazardous results of vision loss due to DR. According to some recent publications a device has been developed to restore the vision loss. This device could be very helpful in future for the restoration of vision loss due to DR [56]. This finding of introducing a device in retina which restores the vision loss is very feasible. The feasibility of this strategy is because of the stimulus which is introduced at that place where already the light-sensitive cells have been used to exist. This stimulus takes advantage of the downstream process. This downstream process always occurs in retinal neurons before the signals reach the visual cortex. This finding supports the stem cell replacement strategy.

The mesenchymal cells are considered to be the new players in the treatment of the DR. As earlier we have also discussed about the neuroprotection in retina. Mesenchymal cells are very convenient in terms of neuroprotection in retina. Adipose stromal cells ASCs are also very important in terms of their role. ASCs develop the antiapoptotic and angiogenic effects. These effects are beneficial in terms of protection of capillaries and neurodegeneration [57]. The application of ASCs is through the intravenous injections. These injections first 
experimented on rats and they demonstrated good results. These injections also normalize the blood glucose level as well as with the treatment of DR. Stem cells are the most feasible source for a long term satisfying results for DR. Potential of stem cells in cell therapy is controlled through various objects. These factors enhance the potential of stem cells [58]. Now a day's new strategies are developed to enhance the potential of stem cells to cure the neural cells and vascular cells of retina.

\section{Dr. management}

Along with the stem cell therapy for DR treatment many other factors are also involved in management of diabetic retinopathy. For example, blood glucose level and blood pressure level management (Fig 4).

\section{Glucose level}

Hyperglycemia and its duration is the main cause of progression of DR [59]. Due to the mismanagement in the glucose level exerts many hazardous results. Oxidative stress exerts on the epithelial cell lining that increases the interactions between the circulating inflammatory cells and make them activated [60].

\section{Level of lipids}

High level of lipids also progress the DR. High lipid level results dysfunction of endothelial due to the reduction of availability of nitric oxide. Increase in oxidative stress takes place which results the peroxidation of lipids. This oxidative stress is associated with hyperglycemia. This increased hyperglycemia is responsible for the retinal emanation formation in Dr.

\section{Aldose reductase management}

Increased expression of aldose reductase is responsible for the progression of DR. In hyperglycemic condition the excess of glucose in blood is reduced by aldose reductase to sorbitol at the expense of NADPH. Increase in the level of sorbitol induces the osmotic stress. This osmotic stress reduces the level of NADPH. Glutathione cause the deterioration of antioxidant defense mechanism that results the oxidative damage of retina and capillaries associated with retina.

Level of vascular endothelial growth factor (VEGF)

The maintenance of VEGF level is also very important to overcome the progression of DR. It is an important biomarker in progression of DR. VEGF is also an important permeability-inducing inflammatory agent [61].

\section{Thickening of endothelial membrane}

Thickening of endothelial membrane is also a cause of vision loss in DR. In extra cellular matrix High glucose level stimulates the expressions of mRNA to matrix protein in retinal endothelial cells. This leads to the reduction of the level of degradation of the extracellular matrix protein. The result of all this is the thickening of lower membrane which disturbs the vision function [62].

\section{Oxidative stress}

Hyperglycemia causes the oxidative stress. Continuous high glucose level exerts the change in the regular pathways. This situation reduces the antioxidant enzymes such as CAT and SOD; and co-enzymes $\mathrm{NADH}$ in retina. Deterioration of the antioxidant defense mechanism leads to the oxidation of cellular macromolecules which result the further damage of retina. Management of diabetic retinopathy is according to the duration of diabetes in any patient. Risk factors of DR are also related to the duration of diabetes. Management is different in both type 1 and type 2 diabetes. 


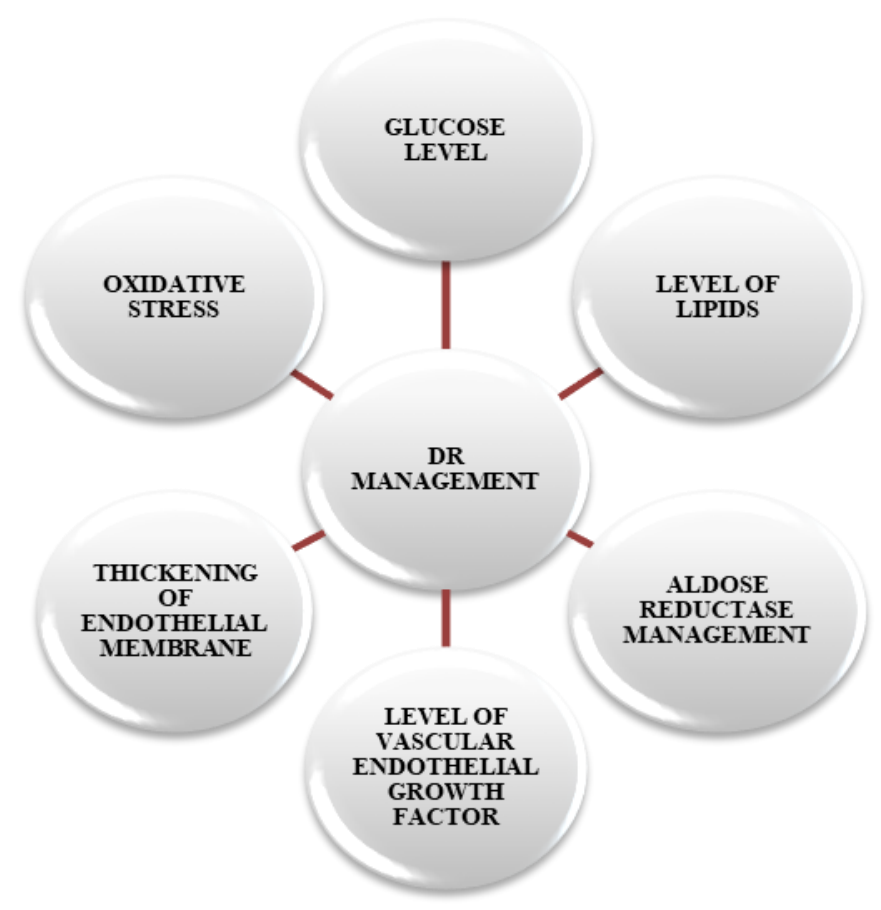

Figure 4. Management of diabetic retinopathy

\section{Dr. management}

Control of blood pressure and lipid level are included in primary pretentious control of glucose level. Diabetic retinopathy is the trending issue of vision loss in the world. The early detection might be helpful to resolve this issue. The diabetic patients are recommended to consult any specialist right after 12 months [63]. After the detection of the disease DR needs a proper treatment. Although DR does not have any proper treatment yet but above prevention are absolutely very helpful. Laser photocoagulation is one of the parts of proper treatment of diabetic retinopathy. There are $50 \%$ patients with proliferative diabetic retinopathy suffering from vision loss. Laser photocoagulation reduces the 3 years' prevalence of vision loss. Many physicians recommend laser photocoagulation to overcome the vision loss. Anti-VEGF (vascular endothelial growth factor) therapy is also feasible. This therapy is convenient to decrease the therapy sessions as per year. Anti-VEGF therapy is a monthly practice.
Aspirin was considered to be one of the treatments but it was found that aspirin therapy did not work for progression of diabetic retinopathy. Especially for the patients who need this for cardiovascular diseases or other conditions [64]. Some steroid based injections are also used for the treatment of diabetic retinopathy.

\section{Intravitreal steroid injections}

Corticosteroids are the anti-inflammatory agents used to cure diabetic retinopathy. These corticosteroids inhibit the activity and expression of the VEGF and also helpful in prevention from the breakdown of bloodretinal barrier. Among the use of corticosteroids; Triamcinolone acetonide TA is more popular. Intravitreal TA is the promising treatment for the patients of macular edemathatdoes not show response on laser treatment. But a continuous application of Intravitreal TA injections is inconvenient for some patients. To overcome this situation a biodegradable intravitreal implant called Retisert has been developed. In case of severe proliferative diabetic retinopathy there 
is a high risk of vision loss. At this stage photocoagulation surgery is one of the promising strategies to restore the vision loss. Scatter laser treatment is also a feasible strategy for restoration of vision loss in case of severe non-proliferative diabetic retinopathy or in case of non-severe proliferative diabetic retinopathy [65].

\section{Screening of Dr.}

Screening of DR is very important for being very helpful in reduction of risk of diabetic retinopathy. Screening and early treatment with laser can reduces the risk of DR. According to the early treatment of diabetic retinopathy Study laser photocoagulation could be helpful in prevention of vision loss even with patients' proliferative diabetic retinopathy.

At this threshold level of DR patients are mostly symptom free. The progression of diabetic retinopathy is based on the duration and severity of diabetes in any patient [66]. Screening is important in terms to identify the diabetic patients suffering from DR. They still in symptomless even with proliferative diabetic retinopathy.

According to current studies in DR the patients who have type 1 diabetes their DR situation should be examined after 5 years of diagnosis. The patients with type 2 diabetes should be examined right after every 1 year. The diabetic patients who become pregnant also have an increased risk of DR. They should examine their DR status in their $1^{\text {st }}$ trimester [67]. Screening is very important even you are just new diagnosed diabetic patient. Photocoagulation is feasible even for the screening of macular edema [68]. Along with the above techniques of screening risk of diabetic retinopathy could be managed. Although there is not any particular strategy for DR treatment but along with the stem cell therapy management and screening of DR are the most feasible strategies to overcome the risk of diabetic retinopathy.

\section{Conclusion}

This study is about the prospect of stem cells in diabetic retinopathy, its management and screening. Diabetic retinopathy is the trending cause of vision loss. Stem cells have the potential restore the vision loss in diabetic retinopathy. Different stem cells like mesenchymal stem cells, induced pluripotent stem cells, CD34+ cells and HLA factors have different aspects of effectiveness in diabetic retinopathy treatment. Along with the stem cells many other strategies for example; laser photocoagulation, anti-VEGF therapy, intravitreal injections and scatter laser therapy. Despite of all the proper treatment risk of diabetic retinopathy need to be manage. Management of diabetic retinopathy includes the management of glucose level, lipid level, aldose reductase level and level of VEGF. The management of all the above factors can reduce the severity of diabetic retinopathy. Screening of diabetic retinopathy is also a part of the management of this disease. Proper screening of diabetic retinopathy can reduce the risk of vision loss. Although there is not any strategy yet that can completely nullify the risk of diabetic retinopathy but stem cell therapy, proper treatment, management and screening can reduce the risk of vision loss from diabetic retinopathy.

\section{Authors' contributions}

Conceived and designed the experiments: MS Shahzad, Performed the experiments: L Batool, Analyzed the data: A Arif, R Ahmed, Contributed materials/ analysis/ tools: MS Shahzad, Wrote the paper: R Ahmed \& KR Khan.

\section{Acknowledgement}

Authors acknowledge University of Central Punjab for providing all the facilities required to write this review article.

\section{References}

1. Coughlin RP, Oldweiler A, Mickelson DT \& Moorman III CT (2017). AdiposeDerived Stem Cell Transplant Technique 
for Degenerative Joint Disease. Arthros Techniq 6(5): e1761-e1766.

2. Berebichez-Fridman R, Gómez-García R, Granados-Montiel J, BerebichezFastlicht E, Olivos-Meza A, Granados J, Velasquillo C \& Ibarra C (2017). The Holy Grail of Orthopedic Surgery: Mesenchymal Stem Cells-Their Current Uses and Potential Applications. Stem Cells Inter.

3. Huang Q, Ding Y, Yu JG, Li J, Xiang Y \& Tao N (2021). Induction of Differentiation of Mesenchymal Stem Cells into Retinal Pigment Epithelial Cells for Retinal Regeneration by Using Ciliary Neurotrophic Factor in Diabetic Rats. Curr Med Sci 41: 145-152.

4. Li XJ, Li CY, Bai D \& Leng Y (2021). Insights into stem cell therapy for diabetic retinopathy: a bibliometric and visual analysis. Neu Regen Res 16: 172178.

5. Liu Y \& Lee RK (2021). Cell transplantation to replace retinal ganglion cells faces challenges the Switchboard Dilemma. Neul Regen Res 16: 11381143.

6. Xu H, Curtis T \& Stitt A (2014). Pathophysiology and Pathogenesis of Diabetic Retinopathy. Amsterdam: Diapedia, The Living Textbook of Diabetes.

7. Wilkinson CP, Ferris III FL, Klein RE, Lee PP, Agardh CD, Davis M, Dills D, Kampik A, Pararajasegaram R, Verdaguer JT \& Group GD (2003). Proposed international clinical diabetic retinopathy and diabetic macular edema disease severity scales. Ophthalmol 110(9): 1677-1682.

8. Fong DS, Aiello L, Gardner TW, King GL, Blankenship G, Cavallerano JD, Ferris FL \& Klein R (2004). Retinopathy in diabetes. Diabetes Care 27(Suppl 1): s84-s87.
9. Porada CD, Zanjani Ed \& AlmeidaPorada G (2006). Adult mesenchymal stem cells: a pluripotent population with multiple applications. Curr Stem Cell Res Ther 1(3): 365-369.

10. Lund RD, Wang S, Lu B, Girman S, Holmes T, Sauve Y, Messina DJ, Harris IR, Kihm AJ, Harmon Am \& Chin FY (2007). Cells isolated from umbilical cord tissue rescue photoreceptors and visual functions in a rodent model of retinal disease. Stem Cells 25(3): 602611.

11. Ejaz S, Chekarova I, Ejaz A, Sohail A \& Lim CW (2008). Importance of pericytes and mechanisms of pericyte loss during diabetic retinopathy. Diabetes Obes Metab 10(1): 53-63.

12. Zhang Y \& Wang W (2010). Effects of bone marrow mesenchymal stem cell transplantation on light-damaged retina. Invest Ophthalmol Vis Sci 51(7): 3742-3748.

13. Park TS, Huo JS, Peters A, Talbot Jr CC, Verma K, Zimmerlin L, Kaplan IM \& Zambidis ET (2012). Growth factoractivated stem cell circuits and stromal signals cooperatively accelerate nonintegrated iPSC reprogramming of human myeloid progenitors. PLoS One 7(8): e42838.

14. Sharma R, Khristov V, Rising A, Jha BS, Dejene R, Hotaling N, Li Y, Stoddard J, Stankewicz C, Wan Q \& Zhang C (2019). Clinical-grade stem cell-derived retinal pigment epithelium patch rescues retinal degeneration in rodents and pigs. Sci Transl Med 11(475): eaat5580.

15. Da Cruz L, Fynes K, Georgiadis O, Kerby J, Luo YH, Ahmado A, Vernon A, Daniels JT, Nommiste B, Hasan SM \& Gooljar SB (2018). Phase 1 clinical study of an embryonic stem cell-derived retinal pigment epithelium patch in age-related macular degeneration. Nat Biotechnol 36(4): 328. 
16. Osakada F, Ikeda H, Mandai M, Wataya T, Watanabe K, Yoshimura N, Akaike A, Sasai Y \& Takahashi M (2008). Toward the generation of rod and cone photoreceptors from mouse, monkey and human embryonic stem cells. Nat Biotechnol 26: 215-224.

17. Takahashi K \& Yamanaka S (2006). Induction of pluripotent stem cells from mouse embryonic and adult fibroblast cultures by defined factors. Cell 126(4): 663-676.

18. Bhatia B, Singhal S, Jayaram H, Khaw PT \& Limb GA (2010). Adult retinal stem cells revisited. Open Ophthalmol J 4: 30 .

19. Zhang W, Chen S \& Liu ML (2018). Pathogenic roles of microvesicles in diabetic retinopathy. Acta Pharmacol $\operatorname{Sin}$ 39(1): 1 .

20. Caballero S, Sengupta N, Afzal A, Chang KH, Calzi SL, Guberski DL, Kern TS \& Grant MB (2007). Ischemic vascular damage can be repaired by healthy, but not diabetic, endothelial progenitor cells. Diabetes 56(4): 960-967.

21. Caballero S, Hazra S, Bhatwadekar A, Calzi SL, Paradiso LJ, Miller LP, Chang LJ, Kern TS \& Grant MB (2013). Circulating mononuclear progenitor cells: differential roles for subpopulations in repair of retinal vascular injury. Invest Ophthalmol Vis Sci 54(4): 3000-3009.

22. Traktuev DO, Merfeld-Clauss S, Li J, Kolonin M, Arap W, Pasqualini R, Johnstone BH \& March KL (2008). A population of multipotent CD34-positive adipose stromal cells share pericyte and mesenchymal surface markers, reside in a periendothelial location, and stabilize endothelial networks. Circ Rec 102(1): 77-85.

23. Wagner W, Horn P, Castoldi M, Diehlmann A, Bork S, Saffrich R, Benes V, Blake J, Pfister S, Eckstein V \& Ho AD (2008). Replicative senescence of mesenchymal stem cells: a continuous and organized process. PloS One 3(5): e2213.

24. Karlstetter M, Scholz R, Rutar M, Wong WT, Provis JM \& Langmann T (2015). Retinal microglia: just bystander or target for therapy. Prog Retin Eye Res 45: 3057.

25. An X, Li L, Chen Y, Luo A, Ni Z, Liu J, Yuan Y, Shi M, Chen B, Long D \& Cheng J (2016). Mesenchymal stem cells ameliorated glucolipotoxicity in HUVECs through TSG-6. Inter J Mol Sci 17(4): 483.

26. Murugeswari P, Shukla D, Rajendran A, Kim R, Namperumalsamy P \& Muthukkaruppan V (2008). Proinflammatory cytokines and angiogenic and anti-angiogenic factors in vitreous of patients with proliferative diabetic retinopathy and eales'disease. Retina 28(6): 817-824.

27. Capitão M \& Soares R (2016). Angiogenesis and inflammation crosstalk in diabetic retinopathy. $J$ Cell Biochem 117(11): 2443-2453.

28. Bassi ÊJ, Moraes-Vieira PM, Moreira-Sá CS, Almeida DC, Vieira LM, Cunha CS, Hiyane MI, Basso AS, Pacheco-Silva A \& Câmara NO (2012). Immune regulatory properties of allogeneic adipose-derived mesenchymal stem cells in the treatment of experimental autoimmune diabetes. Diabetes 61(10): 2534-2545.

29. Ezquer M, Urzua CA, Montecino S, Leal $\mathrm{K}$, Conget $\mathrm{P}$ \& Ezquer $\mathrm{F}$ (2016). Intravitreal administration of multipotent mesenchymal stromal cells triggers a cytoprotective microenvironment in the retina of diabetic mice. Stem Cell Res Ther 7(1): 42.

30. Yan Z, Zhuansun Y, Chen R, Li J \& Ran $P$ (2014). Immunomodulation of mesenchymal stromal cells on regulatory 
T cells and its possible mechanism. Exp Cell Res 324(1): 65-74.

31. Cao YL, Zhang FQ \& Hao FQ (2016). Th1/Th2 cytokine expression in diabetic retinopathy. Gen Mol Res 15(3): 1-9.

32. Urbančič M, Kloboves Prevodnik V, Petrovič D \& Globočnik Petrovič M (2013). A flow cytometric analysis of vitreous inflammatory cells in patients with proliferative diabetic retinopathy. Bio Med Res Inter.

33. Van Ark J, Moser J, Lexis CP, Bekkema F, Pop I, van der Horst IC, Zeebregts CJ, van Goor $\mathrm{H}$, Wolffenbuttel $\mathrm{BH} \&$ Hillebrands JL (2012). Type 2 diabetes mellitus is associated with an imbalance in circulating endothelial and smooth muscle progenitor cell numbers. Diabetologia 55(9): 2501-2512.

34. Kusuyama T, Omura T, Nishiya D, Enomoto S, Matsumoto R, Takeuchi K, Yoshikawa J \& Yoshiyama M (2006). Effects of treatment for diabetes mellitus on circulating vascular progenitor cells. $J$ Pharmacol Sci 102(1): 96-102.

35. Chakravarthy U, Harding SP, Rogers CA, Downes SM, Lotery AJ, Culliford LA, Reeves BC \& IVAN Study Investigators (2013). Alternative treatments to inhibit VEGF in age-related choroidal neovascularisation: 2-year findings of the IVAN randomised controlled trial. Lancet 382(9900): 1258-1267.

36. Do DV, Nguyen QD, Boyer D, SchmidtErfurth U, Brown DM, Vitti R, Berliner AJ, Gao B, Zeitz O, Ruckert R \& Schmelter T (2012). One-year outcomes of the da Vinci Study of VEGF Trap-Eye in eyes with diabetic macular edema. Ophthalmol 119(8): 1658-1665.

37. Petrus-Reurer S (2018). Human embryonic stem cells for retinal repair: preclinical in vitro and in vivo studies for the treatment of age-related macular degeneration with human embryonic stem cell-derived retinal pigment epithelial cells.

38. West EL, Pearson RA, MacLaren RE, Sowden JC \& Ali RR (2009). Cell transplantation strategies for retinal repair. Prog Brain Res 175: 3-21.

39. Gariano RF \& Gardner TW (2005). Retinal angiogenesis in development and disease. Nat 438(7070): 960.

40. Stitt AW, O'Neill CL, O'Doherty MT, Archer DB, Gardiner TA \& Medina RJ (2011). Vascular stem cells and ischaemic retinopathies. Prog Retin Eye Rec 30(3): 149-166.

41. Park SS, Caballero S, Bauer G, Shibata B, Roth A, Fitzgerald PG, Forward KI, Zhou P, McGee J, Telander DG \& Grant MB (2012). Long-term effects of intravitreal injection of GMP-grade bone-marrowderived CD34+ cells in NOD-SCID mice with acute ischemia-reperfusion injury. Invest Ophthalmol Vis Sci 53(2): 986994.

42. Ong JM \& Da Cruz L (2012). A review and update on the current status of stem cell therapy and the retina. $\mathrm{Br}$ Med Bull 102(1): 133-146.

43. Yang Z, Li K, Yan X \& Dong F \& Zhao C (2010). Amelioration of diabetic retinopathy by engrafted human adiposederived mesenchymal stem cells in streptozotocin diabetic rats. Graefes Arch Clin Exp Ophthalmol 248(10): 14151422.

44. Haddad-Mashadrizeh A, Bahrami AR, Matin MM, Edalatmanesh MA, Zomorodipour A, Gardaneh $\mathrm{M}$, Farshchian M \& Momeni-Moghaddam M (2013). Human adipose-derived mesenchymal stem cells can survive and integrate into the adult rat eye following xenotransplantation. Xenotransplantatio $n$ 20(3): 165-176.

45. Zhou L, Wang W, Liu Y, de Castro JF, Ezashi T, Telugu BP, Roberts RM, Kaplan HJ \& Dean DC (2011). 
Differentiation of induced pluripotent stem cells of swine into rod photoreceptors and their integration into the retina. Stem Cells 29(6): 972-980.

46. Maeda T, Lee MJ, Palczewska G, Marsili S, Tesar PJ, Palczewski K, Takahashi M \& Maeda A (2013). Retinal pigmented epithelial cells obtained from human induced pluripotent stem cells possess functional visual cycle enzymes in vitro and in vivo. Biol Chem 288(48): 3448434493.

47. Borooah S, Phillips MJ, Bilican B, Wright AF, Wilmut I, Chandran S, Gamm D \& Dhillon B (2013). Using human induced pluripotent stem cells to treat retinal disease. Prog Retin Eye Res 37: 163-181.

48. Zhu Y, Carido M, Meinhardt A, Kurth T, Karl MO, Ader M \& Tanaka EM (2013). Three-dimensional neuroepithelial culture from human embryonic stem cells and its use for quantitative conversion to retinal pigment epithelium. PloS One 8(1): e54552.

49. Takahashi K \& Yamanaka S (2006). Induction of pluripotent stem cells from mouse embryonic and adult fibroblast cultures by defined factors. Cell 126(4): 663-676.

50. Couturier AG, Blot L, Vignaud C, Nanteau A, Slembrouck-Brec V, Fradot N, Acar JA, Sahel R, Tadayoni G, Thuret F, Sennlaub JE, Roger O, Goureau X, Guillonneau \& Reichman S (2021). Reproducing diabetic retinopathy features using newly developed human induced pluripotent stem cell-derived retinal Muller glial cells. Glia.

51. Nakagawa M, Koyanagi M, Tanabe K, Takahashi K, Ichisaka T, Aoi T, Okita K, Mochiduki $\mathrm{Y} \&$ Takizawa $\mathrm{N} \&$ Yamanaka S (2008). Generation of induced pluripotent stem cells without Myc from mouse and human fibroblasts. Nat Biotechnol 26(1): 101.
52. Da Cruz L, Chen FK, Ahmado A, Greenwood J \& Coffey P (2007). RPE transplantation and its role in retinal disease. Prog Retin Eye Res 26(6): 598635.

53. Buchholz DE, Hikita ST, Rowland TJ, Friedrich AM, Hinman CR, Johnson LV \& Clegg DO (2009). Derivation of functional retinal pigmented epithelium from induced pluripotent stem cells. Stem Cells 27(10): 2427-2434.

54. Carr AJ, Vugler AA, Hikita ST, Lawrence JM, Gias C, Chen LL, Buchholz DE, Ahmado A, Smart MJ, Hasan S \& da Cruz L (2009). Protective effects of human iPS-derived retinal pigment epithelium cell transplantation in the retinal dystrophic rat. PloS One 4(12): e8152.

55. Zrenner E, Bartz-Schmidt KU, Benav H, Besch D, Bruckmann A, Gabel VP, Gekeler F, Greppmaier U, Harscher A, Kibbel S \& Koch J (2010). Subretinal electronic chips allow blind patients to read letters and combine them to words. Proc Biol Sci 278(1711): 14891497.

56. Rehman J, Traktuev D, Li J, MerfeldClauss S, Temm-Grove CJ, Bovenkerk JE, Pell CL, Johnstone BH, Considine RV \& March KL (2004). Secretion of angiogenic and antiapoptotic factors by human adipose stromal cells. Circulation 109(10): 1292.

57. Ueki Y, Wilken MS, Cox KE, Chipman L, Jorstad N, Sternhagen K, Simic M, Ullom K, Nakafuku M \& Reh TA (2015). Transgenic expression of the proneural transcription factor Ascl1 in Müller glia stimulates retinal regeneration in young mice. Proc Natl Acad Sci 112(44): 13717-13722.

58. Cetin EN, Bulgu Y, Ozdemir S, Topsakal S, Akın F, Aybek H \& Yıldırım C (2013). Association of serum lipid levels with 
diabetic retinopathy. Inter $J$ of Ophthalmol 6(3): 346.

59. Rema M, Srivastava BK, Anitha B, Deepa R \& Mohan V (2006). Association of serum lipids with diabetic retinopathy in urban South Indians - the Chennai Urban Rural Epidemiology Study (CURES) Eye Study-2. Diabet Med 23(9): 1029-1036.

60. Roy S, Ha J, Trudeau K \& Beglova E (2010). Vascular basement membrane thickening in diabetic retinopathy. Curr Eye Res 35(12): 1045-1056.

61. Pan HZ, Zhang H, Chang D, Li H \& Sui $\mathrm{H}$ (2008). The change of oxidative stress products in diabetes mellitus and diabetic retinopathy. Br J Ophthalmol 92(4): 548551.

62. Bandello F, Cunha-Vaz J, Chong NV, Lang GE, Massin P, Mitchell P, Porta M, Prünte C, Schlingemann R \& SchmidtErfurth U (2012). New approaches for the treatment of diabetic macular oedema: recommendations by an expert panel. Eye 26(4): 485.

63. Elman MJ, Qin H, Aiello LP, Beck RW, Bressler NM, Ferris III FL, Glassman AR, Maturi RK \& Melia M (2012). Diabetic Retinopathy Clinical Research Network. Intravitrealranibizumab for diabetic macular edema with prompt versus deferred laser treatment: threeyear randomized trial results. Opthamol 119(11): 2312-2318.

64. Bhavsar AR (2006). Diabetic retinopathy: the latest in current management. Retina 26(6): S71-S79.

65. Silva PS, Cavallerano JD, Sun JK, Aiello LM \& Aiello LP (2010). Effect of systemic medications on onset and progression of diabetic retinopathy. Net Rev Endocrinol 6(9): 494.

66. Keenum Z, McGwin G, Witherspoon CD, Haller JA, Clark ME \& Owsley C (2016). Patients' adherence to recommended follow-up eye care after diabetic retinopathy screening in a publicly funded county clinic and factors associated with follow-up eye care use. JAMA Opthalmol 134(11): 12211228.

67. Solomon SD, Chew E, Duh EJ, Sobrin L, Sun JK, VanderBeek BL, Wykoff CC \& Gardner TW (2017). Diabetic retinopathy: a position statement by the American Diabetes Association. Diabetes Care 40(3): 412418.

68. El Rami H, Barham R, Sun JK \& Silva PS (2017). Evidence-based treatment of diabetic retinopathy. Semin Ophthalmol 32(1): 67-74. 